\title{
MOTERŲ GIMDYMO IR POGIMDYMINĖS PRIEŽIŪROS LŪKESČIŲ VERTINIMAS MOTERŲ NUOMONE
}

\author{
Alina Liepinaitiené ${ }^{1}$, Ingrida Poškiené $\dot{e}^{1,2}$ \\ ${ }^{l}$ Lietuvos sveikatos mokslu universiteto ligoninès Kauno kliniku Akušerijos ir ginekologijos klinika, \\ ${ }^{2}$ Kauno kolegijos Medicinos fakultetas
}

Raktažodžiai: priežiūros lūkesčiai, sveikatos priežiūros paslaugų kokybè, pogimdyminis laikotarpis, gimdymas.

\begin{abstract}
Santrauka
Paciento prioritetų, lūkesčių vertinimas tampa svarbiu žingsniu siekiant igyvendinti paciento medicininès konsultacijos lūkesčius. Paciento lūkesčiai svarbūs ne tik kaip jo nuomonè, jų pateisinimas turi itakos paciento pasitenkinimui sveikatos priežiūros paslaugomis, gydymo rèžimo bei gydymo tąsos bei gydymo rezultatams. Lietuvoje atliktų tyrimų, kuriuose būtų nagrinėjama pagimdžiusių moterų priežiūros lūkesčiai, rasti nepavyko. Norint, kad sveikatos priežiūros paslaugos būtų kokybiškos, labai svarbu atkreipti dèmesị ne tik ị dokumentus, kurie reglamentuoja sveikatos priežiūros kokybę, bet ir i pačių moterų prieš gimdymą susiformavusių pogimdyminès priežiūros lūkesčių patenkinimą.

Darbo tikslas buvo ịvertinti moterų priežiūros lūkesčius.
\end{abstract}

Siekiant nustatyti moterų priežiūros lūkesčius, buvo atliktas momentinis tyrimas anketine apklausa. Apklaustos 344 pagimdžiusios moterys, gimdžiusios X klinikoje tiriamuoju laikotarpiu. Tyrimas vykdytas 2015-11-01 - 2016-02-29 laikotarpiu, X klinikos akušerijos skyriuje.

Daugiau nei pusė tyrime dalyvavusių moterų gimdymo ir akušerijos skyrių akušerių darbą ir suteiktą informaciją gimdymo ir pogimdyminiu laikotarpiu ịvertino labai gerai. Daugiau nei pusè moterų teigè, jog gimdymo ir pogimdyminès priežiūros lūkesčiai buvo visiškai pateisinti.

Aukštaji išsimokslinimą turinčios moterys statistiškai reikšmingai dažniau gimdymo ir akušerijos skyrių akušerių darbą ịvertino labai gerai ir gerai nei žemesnį išsimokslinimą turinčios moterys. Statistiškai reikšmingai dažniau ištekejusios moterys gim- dymo ir akušerijos skyrių akušerių suteiktą informaciją ịvertino labai gerai ir gerai nei netekejusios moterys. Dirbančios moterys statistiškai reikšmingai dažniau gimdymo ir pogimdyminès priežiūros lūkesčius laikẻ visiškai ir dalinai pasiteisinusius nei nedirbančios moterys.

\section{Ivadas}

Kiekvienas žmogus turi polinkị kartoti savo tikrojo gimimo istoriją kiekvieną kartą, kai įžengia ị naują gyvenimo ir pažinimo etapą [2]. Psichologai teigia, jei žmogaus gimimas buvo ramus ir lengvas, žmogus kiekvieną gyvenimo etapą pradès lengvai ir pasitikèdamas savimi, tačiau sunkiai gimęs žmogus dažniausiai baimingai žvelgia į naujus gyvenimo etapus [17]. Besikeičiant kiekvieno žmogaus gyvenimo etapams, visuomet yra susiduriama su gimdymo kultūros etapu, iš kur ir kyla natūralus žinių poreikis apie gimdymo procesą, gimdymo priežiūrą ir potyrius gimdymo metu $[2,17]$.

Pastaraji dešimtmeti pradèta ypač domètis sveikatos priežiūros paslaugų kokybe. Pacientų apklausos sudaro galimybes sveikatos priežiūros įstaigoms kryptingai tobulinti teikiamų paslaugų kokybę [4]. Irodymais pagrịstos medicinos naudojimas svarbus nagrinejjant temas, susijusias su moterų pogimdyminès priežiūros lūkesčiais, įvertinant moterims teikiamų paslaugų kokybę [8].

Pirmą kartą gimdančios moterys turi susikūrę literatūrinị - iliuzini nèštumo, gimdymo, naujagimio maitinimo ir priežiūros bei viso gyvenimo po gimdymo vaizdą, kuris siejamas su gražia ir pakilia motinyste, natūraliu ir lengvu gimdymu, lengvu naujagimio maitinimu [17]. Pakartotinai gimdančios moterys žino, kas jų laukia ir tam jos yra visiškai kitaip pasiruošę nei pirmą kartą gimdančios moterys [2]. Lietuvoje atliktų tyrimų, kuriuose būtų nagrinejjama pagimdžiusių moterų priežiūros lūkesčiai, nebuvo rasta. Norint, kad sveikatos priežiūros paslaugos būtų kokybiškos, labai svarbu atkreipti dèmesi ne tik ị dokumentus, kurie reglamentuoja sveikatos priežiūros kokybę, bet ị moterų 
prieš gimdymą susiformavusių pogimdyminès priežiūros lūkesčių ịvertinimą.

Pacientų pasitenkinimas jiems teikiamomis sveikatos priežiūros paslaugomis dažnai yra aiškiai nenustatyta koncepcija, kuri dažniausiai atskleidžia tam tikrus priežiūros aspektus [13]. Atliekant pačius pirmuosius pacientų pasitenkinimo tyrimus, dažnai jie būna netikslūs ir neatspindèdavo tikrujjų sveikatos priežiūros kokybès problemų [22]. Pacientų pasitenkinimo ar lūkesčių pateisinimo sveikatos priežiūros paslaugomis klausimynai dar buvo kritikuojami už jų trūkumą atskirti gerą ir blogą sveikatos priežiūrą, kadangi pacientų nebuvo klausiama apie jų pasitenkinimą jų gydymu [3].

Priežiūros lūkesčiai formuojasi dar nėštumo metu ir juos suformuoti padeda sveikatos priežiūros specialistai, ypač akušeriai $[5,11,12,18]$, dirbantys ne tik su néščiomis moterimis, bet ir su gimdyvemis bei moterimis po gimdymo. Tuo tarpu moteru gimdymo patirčiu baigtis ir įvertinimas didžiausia dalimi priklauso nuo sveikatos priežiūros specialisto $[1,5,11,12,18]$, kuris priima gimdymą ir suteikia (arba nesuteikia) moteriai reikalingą informaciją gimdymo metu $[9,10,23]$, bendravimo ir bendradarbiavimo aspektu $[6,14,16,21]$ nepriklausomai nuo kultūrinių $[15,19]$, socialinių [7], tautinių [20] ar ekonominių [20, 21] skirtumų.

$\mathrm{X}$ klinikoje gimdžiusių moterų komplikuoti gimdymai ir pasitikèjimo medicinos personalu sumažejjimas dẻl ịvairių priežasčių blogina moterų santykius su sveikatos priežiūros specialistais bei mažina pasitenkinimą sveikatos priežiūros paslaugomis.

Tyrimo tikslas - ịvertinti moterų gimdymo ir pogimdyminès priežiūros lūkesčius.

\section{Tyrimo metodai ir objektas}

Siekiant nustatyti ir ịvertinti X klinikoje gimdžiusiu moteru priežiūros lūkesčius, buvo sudarytas klausimynas iš 33 klausimų ir atliktas momentinis tyrimas (angl. ,,crosssectional study") anketine apklausa. Kadangi Lietuvoje pasirinktai tyrimo temai tinkamo tyrimo instrumento surasti nepavyko, anketa buvo sudaryta autoriu sukurtais atvirais ir uždarais klausimais. Kartu anketoje pateikti klausimai, atspindintys tiriamujų sociodemografinius duomenis.

Nuo 2015 m. lapkričio 1 d. iki 2016 m. vasario 29 d. buvo atliekama anketinè apklausa, sudaryta iš 33 klausimų, X klinikos akušerijos skyriuje, kur buvo apklaustos 344 pagimdžiusios moterys (atsako dažnis 94,8 proc.).

Lietuvos sveikatos mokslų universiteto Bioetikos komisija davė raštišką leidimą (2015-10-20 Nr. BEC-AK(B)-17) atlikti tyrimą X klinikoje.

Tyrimo metodai: mokslinès literatūros analize; statistinè duomenų analizè, naudojant SPSS 22.0 (aprašomoji
1 lentelè. Tiriamųjų charakteristikos $(\mathrm{N}=344)$

\begin{tabular}{|c|c|c|c|}
\hline \multicolumn{2}{|c|}{$\begin{array}{l}\text { Sociodemografinès charakteris- } \\
\text { tikos }\end{array}$} & \multirow{2}{*}{$\begin{array}{c}\begin{array}{c}\text { Atvejai } \\
(\mathbf{N})\end{array} \\
7 \\
31 \\
106 \\
134 \\
49 \\
11 \\
6 \\
\end{array}$} & \multirow{2}{*}{$\begin{array}{c}\begin{array}{c}\text { Procentai } \\
(\%)\end{array} \\
2,0 \\
9,0 \\
30,8 \\
39,0 \\
14,3 \\
3,2 \\
1,7\end{array}$} \\
\hline Amžius & $\begin{array}{c}\text { Iki } 18 \mathrm{~m} . \\
18-22 \mathrm{~m} . \\
23-27 \mathrm{~m} . \\
28-32 \mathrm{~m} . \\
33-37 \mathrm{~m} . \\
38-42 \mathrm{~m} . \\
\text { Nuo } 43 \mathrm{~m} .\end{array}$ & & \\
\hline $\begin{array}{l}\text { Išsimoksli- } \\
\text { nimas }\end{array}$ & $\begin{array}{c}\text { Pradinis } \\
\text { Pagrindinis } \\
\text { Vidurinis } \\
\text { Aukštesnysis } \\
\text { Aukštasis } \\
\text { Kita (neturi išsi- } \\
\text { mokslinimo) }\end{array}$ & $\begin{array}{c}6 \\
39 \\
49 \\
29 \\
211 \\
10\end{array}$ & $\begin{array}{c}1,7 \\
11,4 \\
14,3 \\
8,4 \\
61,3 \\
2,9\end{array}$ \\
\hline $\begin{array}{l}\text { Šeiminè pa- } \\
\text { dètis }\end{array}$ & $\begin{array}{c}\text { Netekèjusi } \\
\text { Ištekejjusi } \\
\text { Išsiskyrusi } \\
\text { Gyvena su par- } \\
\text { tneriu }\end{array}$ & $\begin{array}{c}56 \\
241 \\
4 \\
43\end{array}$ & $\begin{array}{c}16,3 \\
70,0 \\
1,2 \\
12,5\end{array}$ \\
\hline $\begin{array}{l}\text { Gyvenamoji } \\
\text { vieta }\end{array}$ & $\begin{array}{c}\text { Didmiestis } \\
\text { Miestas } \\
\text { Miestelis } \\
\text { Kaimas }\end{array}$ & $\begin{array}{l}157 \\
105 \\
25 \\
57\end{array}$ & $\begin{array}{c}45,6 \\
30,5 \\
7,3 \\
16,6\end{array}$ \\
\hline $\begin{array}{l}\text { Socialinè pa- } \\
\text { dètis }\end{array}$ & $\begin{array}{c}\text { Namų šeimi- } \\
\text { ninké } \\
\text { Dirbanti } \\
\text { Studentė } \\
\text { Bedarbe் } \\
\text { Kita (moksleivé) }\end{array}$ & $\begin{array}{c}30 \\
268 \\
19 \\
17 \\
10 \\
\end{array}$ & $\begin{array}{c}8,7 \\
77,9 \\
5,5 \\
4,9 \\
2,9\end{array}$ \\
\hline $\begin{array}{l}\text { Gimdymų } \\
\text { skaičius }\end{array}$ & $\begin{array}{c}1 \text { gimdymas } \\
2 \text { gimdymai } \\
3 \text { ir daugiau } \\
\text { gimdymų }\end{array}$ & $\begin{array}{c}245 \\
62 \\
37\end{array}$ & $\begin{array}{l}71,2 \\
18,0 \\
10,8\end{array}$ \\
\hline
\end{tabular}

statistika).

Anketine apklausa buvo apklausiamos visos (344 moterys) 2015 metais X klinikoje tiriamuoju laikotarpiu gimdžiusios moterys.

Rezultatuose analizuojamos 344 anketos, kurios reprezentuoja X klinikoje gimdžiusių moterų priežiūros lūkesčius. Tiriamujų sociodemografinès charakteristikos nurodytos 1 lenteleje. (1 pav.).

\section{Tyrimo rezultatai}

Šiuo darbu buvo siekiama nustatyti pacienčių, gimdžiusių X klinikoje, gimdymo ir pogimdyminio laikotarpio priežiūros patenkinimą. Nustatyta, kad 83,7 proc. moterų gimdymo metu gautą informaciją ịvertino labai gerai ir gerai $\left(\chi^{2}=29,451 ; p<0,05\right)$ ( 1 pav. $)$ o 77,7 proc. moteru 
gydytojo akušerio-ginekologo ir akušerès komandinį darbą gimdymo metu ịvertino labai gerai ir gerai $\left(\chi^{2}=73,815\right.$; $\mathrm{p}<0,001)(2$ pav. $)$.

79,7 proc. tyrime dalyvavusių moteru teigè, jog gimdymo skyriaus akušerių darbas buvo labai geras ir geras (3 pav.), dèl to 67,7 proc. moterų gimdymo priežiūros lūkesčius laike visiškai ir dalinai pasiteisinusius $\left(\chi^{2}=45,391\right.$; $\mathrm{p}<0,001)$ (4 pav.).

Nustatyta, kad 48,2 proc. aukštaji išsimokslinimą turinčių moterų gimdymo skyriaus akušerių darbą įvertino statistiškai reikšmingai $\left(\chi^{2}=28,501 ; p<0,05\right)$ geriau nei žemesnį išsimokslinimą turinčios moterys (5 pav.).

Dirbančios, didmiestyje gyvenančios moterys gimdymo skyriaus akušerių darbą įvertino statistiškai reikšmingai $(p<0,05)$ geriau nei nedirbančios ir gyvenančios kaime ar miestelyje moterys.

54,0 proc. ištekejjusių moterų gimdymo skyriaus akušerių suteiktą informaciją gimdymo metu ịvertino kaip labai gerą ir gerą $\left(\chi^{2}=19,371 ; p<0,001\right)$, kai tuo tarpu labai blogai ir blogai informacija gimdymo metu buvo suteikta 11,0

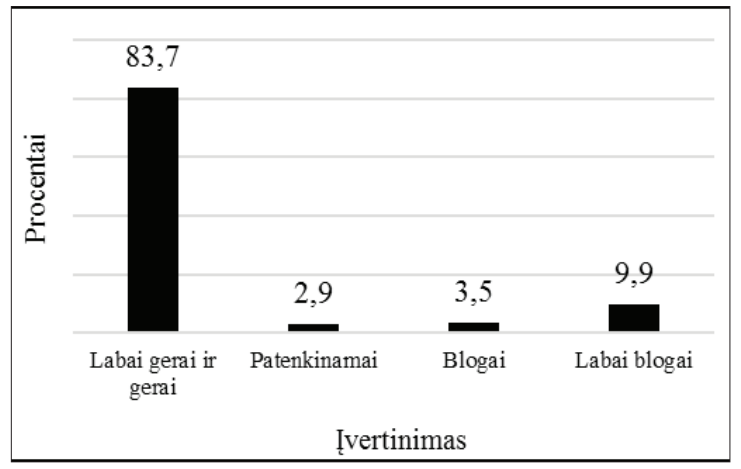

1 pav. Gimdymo skyriaus akušerių suteiktos informacijos ivvertinimas $(\mathrm{N}=344)$.

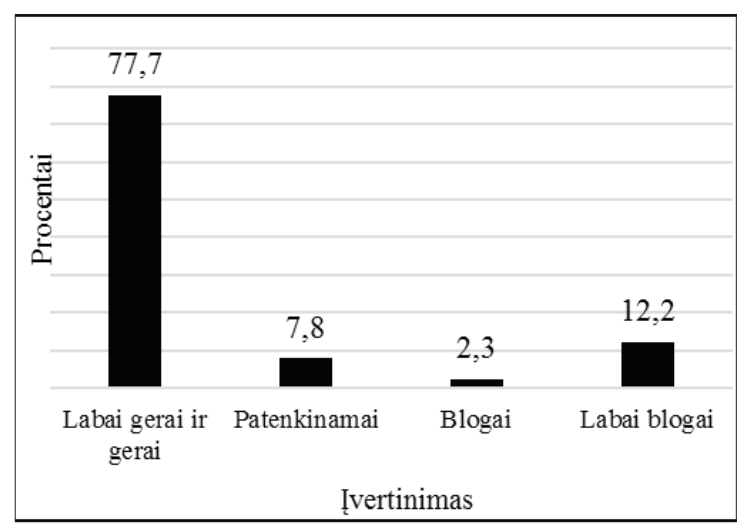

2 pav. Gimdymo skyriaus personalo komandinio darbo ivertinimas $(\mathrm{N}=344)$. proc. moterų.

Akušerijos skyriuje atlikto tyrimo metu nustatyta, kad 92,1 proc. moterų, dalyvavusių tyrime, akušerijos skyriuje suteiktą informaciją vertina labai gerai ir gerai $\left(\chi^{2}=42,313\right.$; $\mathrm{p}<0,001)$, o saugios ir dalinai saugios pogimdyminiu laikotarpiu jautėsi 96,2 proc. moteru $\left(\chi^{2}=39,538 ; \mathrm{p}<0,001\right)$. Dirbančios, gyvenančios dideliame mieste, ištekejusios moterų akušerių suteiktą informaciją $(\mathrm{p}<0,05)$ vertino palankiau nei nedirbančios, netekèjusios, gyvenančios miestelyje ar kaime moterys.

Didžioji dalis moteru ( 83,1 proc.) laiką po gimdymo akušerijos skyriuje ịvertino labai gerai ir gerai $\left(\chi^{2}=12,953\right.$; $\mathrm{p}<0,05)$ (6 pav.). Respondentès paminejo, jog pirmasis ispūdis, atvykus ị akušerijos skyrių, ir personalo empatija joms leido skyriuje jaustis ramiai ir saugiai.

71,8 proc. moteru $\left(\chi^{2}=16,195 ; \mathrm{p}<0,05\right)$ nurode, jog pogimdyminès ir naujagimio priežiūros lūkesčiai akušerijos skyriuje buvo visiškai pateisinti (7 pav.) dèl kvalifikuoto

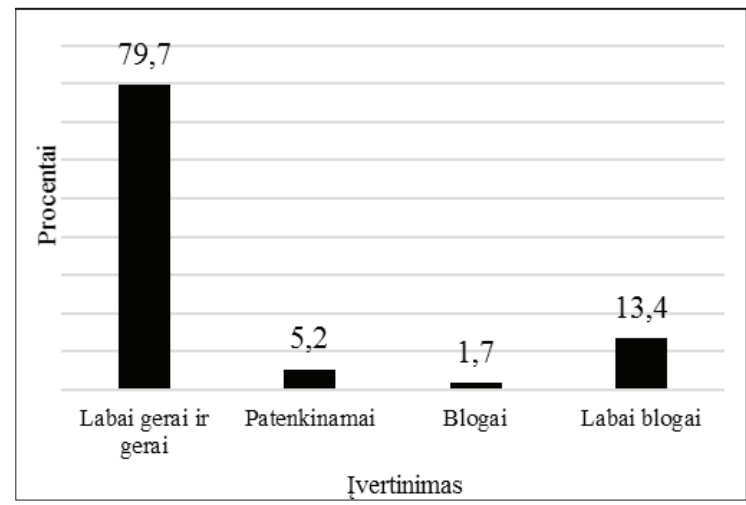

3 pav. Gimdymo skyriaus akušerių darbo ịvertinimas $(\mathrm{N}=344)$.

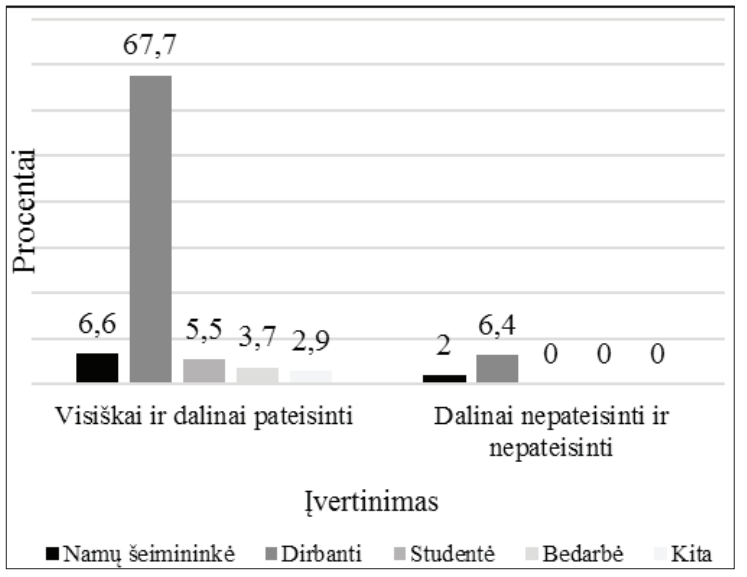

4 pav. Gimdymo priežiūros lūkesčių patenkinimo ịvertini$\operatorname{mas}(\mathrm{N}=344)$. 


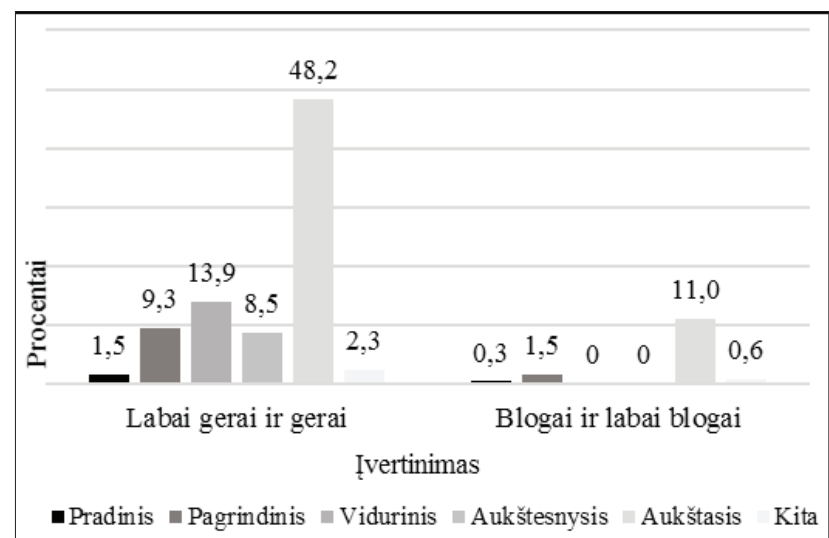

5 pav. Akušerių informacijos suteikimo ir moterų išsimokslinimo ryšio ịvertinimas $(\mathrm{N}=344)$.

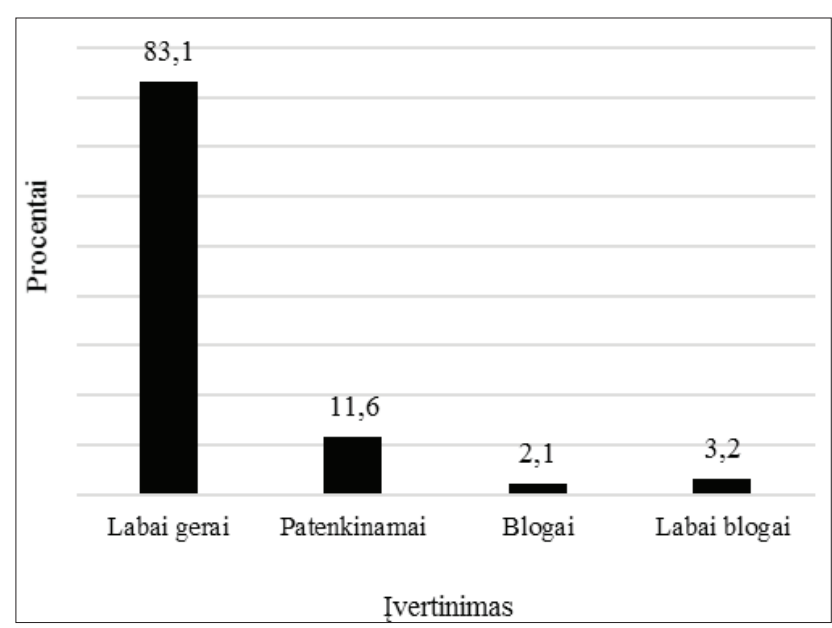

6 pav. Laiko, praleisto akušerijos skyriuje po gimdymo, ịvertinimas $(\mathrm{N}=344)$.

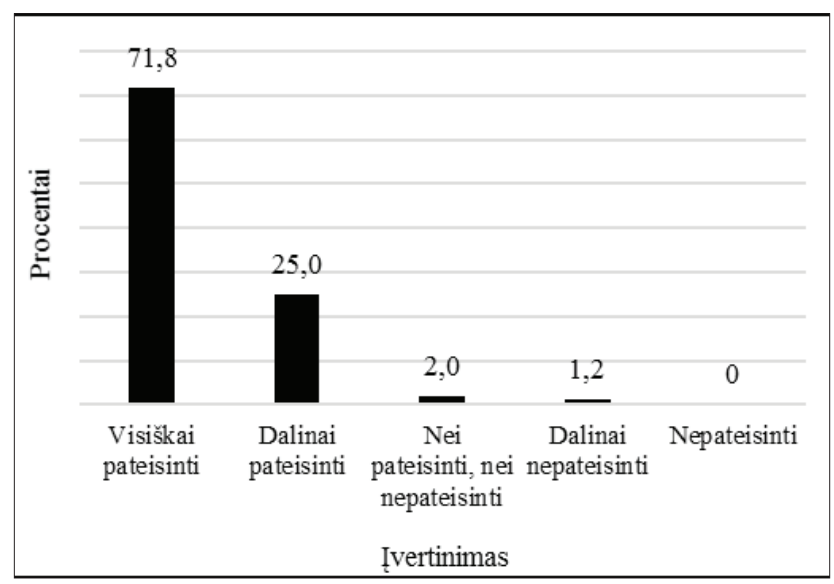

7 pav. Pogimdyminès priežiūros lūkesčių ịvertinimas $(\mathrm{N}=344)$.

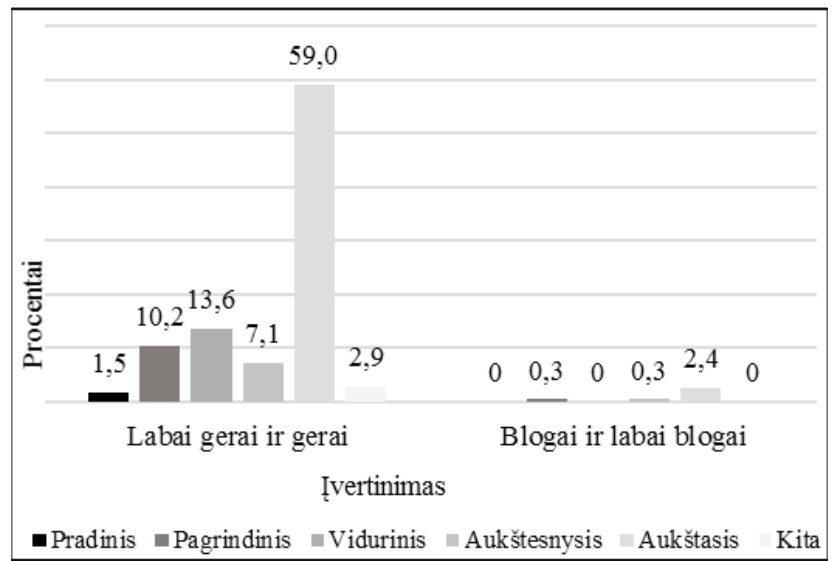

8 pav. Akušeriu darbo ir moteru išsimokslinimo ryšio įvertinimas $(\mathrm{N}=344)$.

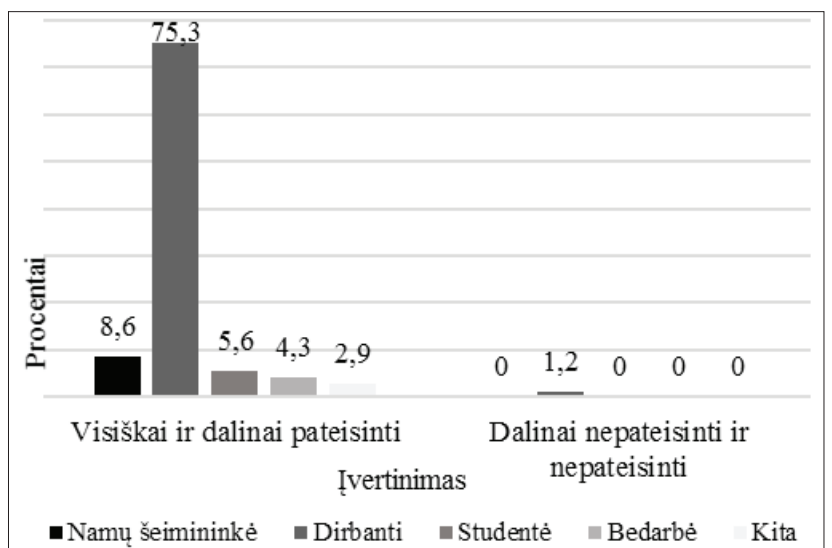

9 pav. Pogimdyminès priežiūros lūkesčių ir moterų socialinès padèties ryšio įvertinimas $(\mathrm{N}=344)$.

personalo pagalbos ir suteiktos informacijos pogimdyminiu laikotarpiu.

Vertinant moterų išsimokslinimo ir akušerijos skyriaus akušerių darbo ịvertinimo moterų nuomone ryšį nustatyta, kad 59,0 proc. aukštajj išsimokslinimą turinčiu moterų akušerijos skyriaus akušerių darbą ịvertino statistiškai reikšmingai labai gerai ir gerai $\left(\chi^{2}=11,952 ; p<0,001\right)$ nei žemesnį išsimokslinimą turinčios moterys ( 8 pav.).

64,8 proc. ištekejusių moteru statistiškai reikšmingai dažniau akušerių suteiktą informaciją ịvertino labai gerai ir gerai $\left(\chi^{2}=10,920 ; p<0,001\right)$ nei netekejjusios moterys.

Vertinant moterų socialinès padèties ir naujagimių bei moterų pogimdyminès priežiūros lūkesčių patenkinimo ryši nustatyta, $\operatorname{kad} 75,3$ proc. dirbančių moterų statistiškai reikšmingai dažniau pogimdyminès priežiūros lūkesčius laike visiškai ir dalinai pateisintus $\left(\chi^{2}=18,239 ; \mathrm{p}<0,001\right)$ nei moterys, kurios nurodè esančios namų šeimininkèmis (9 pav.). 
Moterų priežiūros lūkesčiu patenkinimas gimdymo ir pogimdyminiu laikotarpiu labiausiai priklauso nuo akušeriu suteiktos informacijos, pagalbos gimdymo metu ir pogimdyminiu laikotarpiu. Nustatyta, kad aukštajji išsimokslinimą turinčios, dirbančios, gyvenančios didmiestyje moterys, kurių amžiaus vidurkis 28 metai, tiek gimdymo skyriaus, tiek akušerijos skyriaus akušerių suteiktą informaciją ir gautą pagalbą gimdymo ir pogimdyminiu laikotarpiu icvertino labai gerai ir gerai.

Dirbančios ir aukštaji išsimokslinimą turinčios, gyvenančios didmiestyje moterys, kurių amžius tarp 28-32 metų gimdymo ir pogimdyminio laikotarpio priežiūros lūkesčius laikè visiškai ir dalinai pasiteisinusius.

Tolimesniuose tyrimuose būtų tikslinga didinti apklaustujų imti, itraukiant ne tik X klinikoje, bet ir kituose Lietuvos stacionaruose gimdžiusias moteris. Taip pat labai svarbu šią problemą nagrinèti ne tik moterų, bet ir jų gydytojų bei moterų artimujų požiūriu ir nustatyti pagrindinius aspektus, kurie turi neigiamos įtakos moterų gimdymo patirtims bei siekti, kad moterų priežiūros lūkesčiai tiek gimdymo metu, tiek pogimdyminiu laikotarpiu moterims būtų patenkinti kiek įmanoma geriau.

\section{Išvados}

1. Daugiau nei puse tyrime dalyvavusių moterų gimdymo skyriaus akušerių darbą, akušerių ir gydytojų akušerių-ginekologų komandinį darbą ir suteiktą informaciją gimdymo metu ịvertino labai gerai. Daugiau nei puse moterų teigè, jog gimdymo priežiūros lūkesčiai buvo visiškai pateisinti.

2. Aukštajị išsimokslinimą turinčios moterys statistiškai reikšmingai dažniau gimdymo skyriaus akušerès darbą įvertino labai gerai ir gerai nei žemesni išsimokslinimą turinčios moterys. Statistiškai reikšmingai dažniau ištekejjusios moterys gimdymo skyriaus akušerių suteiktą informaciją ịvertino labai gerai ir gerai nei netekejusios moterys. Dirbančios moterys statistiškai reikšmingai dažniau gimdymo priežiūros lūkesčius laikè visiškai ir dalinai pateisintus nei nedirbančios moterys.

3. Daugiau nei pusė moterų laiką, praleistą akušerijos skyriuje, ivvertino labai gerai. Daugiau nei du trečdaliai moterų priežiūros lūkesčius akušerijos skyriuje laikè visiškai pateisintus.

4. Statistiškai reikšmingai dažniau aukštaji išsimokslinimą turinčios moterys akušerijos skyriaus akušerių darbą įvertino labai gerai ir gerai nei žemesni išsimokslinimą turinčios moterys. Ištekejjusios moterys statistiškai reikšmingai dažniau akušerijos skyriaus akušerių suteiktą informaciją įvertino labai gerai ir gerai nei netekejusios moterys. Dirbančios moterys statistiškai reikšmingai dažniau prie- žiūros lūkesčius akušerijos skyriuje laikè visiškai ir dalinai pateisintus nei nedirbančios moterys.

\section{Literatūra}

1. Adeniran AS, Aboyeji AP, Fawole AA, Balogun OR, Adesina KT, Adeniran PI. Male partner's role during pregnancy, labour and delivery: expectations of pregnant women in Nigeria. International Journal of Health Sciences, Qassim University 2015; 9(3): 305-313.

http://dx.doi.org/10.12816/0024697

2. Ayers S, Eagle A, Waring H. The effects of childbirth-related post-traumatic stress disorder on women and their relationships: a qualitative study. Psychology, Health and medicine 2006; 11(4):389- 398 .

http://dx.doi.org/10.1080/13548500600708409

3. Badri MA, Attia S, Ustadi AM. Healthcare quality and moderators of patient satisfaction: testing for causality. International Journal of Healthcare Quality Assurance 2009; 22 (4): 382 410.

http://dx.doi.org/10.1108/09526860910964843

4. Brogienė D., Gurevičius R. Pacientų nuomonè apie stacionarinès sveikatos priežiūros paslaugų kokybę. Medicina, 2009; 45(3):226-37.

5. Bruce SG, Blanchard AK, Gurav K, Roy A, Jayanna K, Mohan HL. et al. Preferences for infant delivery site among pregnant women and new mothers in Northern Karnataka, India. BMC Pregnancy and Childbirth 2015; 15(49): 1-10.

http://dx.doi.org/10.1186/s12884-015-0481-8

6. Coutinho E, Rocha A, Pereira C, Silva A, Duarte J, Parreira V. Experiences of motherhood: unmet expectations of immigrant and native mothers, about the Portuguese health system. Aten Primaria 2014; 46:140-144.

http://dx.doi.org/10.1016/S0212-6567(14)70081-2

7. Galle A, Van Parys A-S, Roelens K, Keygnaert I. Expectations and satisfaction with antenatal care among pregnant women with a focus on vulnerable groups: a descriptive study in Ghent. BMC Women's Health 2015; 15(112):1-12.

http://dx.doi.org/10.1186/s12905-015-0266-2

8. Giedrikaitė R., Misevičienė I., Jakušovaitė I. Pacientams suteiktos informacijos apie ligą ir jos eigą vertinimas ligoninèse. Medicina, 2007; 43(8):664-73.

9. Higginbottom GMA, Morgan M, Alexandre M, Chiu Y, Forgeron J, Kocay D. et al. Immigrant women's experiences of maternity-care services in Canada: a systematic review using a narrative synthesis. Systematic Reviews 2015; 4(13):1-30.

10. Hodgkinson EL, Smith DM, Wittkowski A. Women's experiences of their pregnancy a systematic review and meta-synthesis. BMC Pregnancy and Childbirth 2014; 14(330):1-11.

11. Ivonaitis A., Klumbienė J. Pacienčių pasitenkinimas paslaugų kokybe akušerijos stacionaruose. Lietuvos akušerija ir ginekologija, 2006; 9(1):12-15.

12. Jankauskienė D., Rastauskas R. Kokybès gerinimas Pasvalio 
ligoninèje. Viešoji politika ir administravimas, 2008; 26:71-79.

13. Jenkinson C, Coulter A, Bruster S, Richards N, Chandola T. Patients' experiences and satisfaction with healthcare: results of a questionnaire study of specific aspects of care. Qual Saf Healthcare 2002; 11:335-39.

http://dx.doi.org/10.1136/qhc.11.4.335

14. Larson E, Hermosilla S, Kimweri A, Mbaruku GM, Kruk ME. Determinants of perceived quality of obstetric care in rural Tanzania: a cross-sectional study. BMC Health Services Research 2014; 14(483):1-9.

http://dx.doi.org/10.1186/1472-6963-14-483

15. Magoma M, Requejo J, Campbell O, Cousens S, Merialdi M, Filippi V. The effectiveness of birth plans in increasing use of skilled care at delivery and postnatal care in rural Tanzania: a cluster randomised trial. Tropical Medicine and International Health 2013; 18(4): 435-443.

http://dx.doi.org/10.1111/tmi.12069

16. Martinez JM, Delgado M. Women's expectations and evaluation of a maternal educational program. Colomb Med 2013; 44(3):134-138.

17. Nicholls K, Ayers S. Childbirth-related post-traumatic stress disorder in couples: A qualitative study. British journal of health psychology 2007; 12:491 - 509 . http://dx.doi.org/10.1348/135910706X120627

18. Raven J, Broek N, Tao F, Kun H, Tolhurst R. The quality of childbirth care in China: women's voices: a qualitative study. BMC Pregnancy and Childbirth 2015; 15(113):1-8. http://dx.doi.org/10.1186/s12884-015-0545-9

19. Sebo P, Hermann FR, Haller DM. How do GPs in Switzerland perceive their patients' satisfaction and expectations? An observational study. BMJ Open 2015; 5:1-7. http://dx.doi.org/10.1136/bmjopen-2014-007085

20. Tabrizi JS, Askari S, Fardiazar Z, Koshavar H, Gholipour K. Service quality of delivered care from the perception of women with caesarean section and normal delivery. Health Promot Perspect 2014; 4(2): 137-143.

21. Tancred T, Schellenberg J, Marchant T. Using mixed methods to evaluate perceived quality of care in southern Tanzania. International Journal for Quality in Healthcare 2016;1-7. http://dx.doi.org/10.1093/intqhe/mzw002

22. Teno JM, Gozalo PL, Lee IC. et al. Does hospice improve quality of care for persons dying from Dementia? Journal of American Geriatrics Society 2011; 59 (8): 1531-36. http://dx.doi.org/10.1111/j.1532-5415.2011.03505.x

23. Wiegers TA. The quality of maternity care services as expe- rienced by women in the Netherlands. BMC Pregnancy and Childbirth 2009; 9(18):1-8.

http://dx.doi.org/10.1186/1471-2393-9-18

\section{ASSESSMENT OF WOMEN'S EXPECTATIONS OF CARE}

\section{A. Liepinaitienè, I. Poškienè}

Key words: expectations of care, healthcare quality, postpartum period, childbirth.

The patient's priorities, expectations, evaluation becomes an important step towards the implementation of the patient's medical advice expectations. Patient expectations are important not only as his opinion, their justification affect patient satisfaction with healthcare services, treatment regime and the continuation of treatment, and treatment outcomes. There were no other survey in Lithuania to carry out trials to examine the care of women given birth expectations. In order that healthcare services are of high quality, it is very important to pay attention not only to the documents that govern the quality of care, but also the women themselves prenatal formed postpartum care expectations.

The aim of work: to assess women's expectations of care.

In order to determine women's expectations of care, was conducted instantaneous survey questionnaire survey women who gave birth. There were 344 postpartum women, who gave birth at $\mathrm{X}$ clinic. Study conducted from $1^{\text {st }}$ November 2015 till $29^{\text {th }}$ February 2016 in Obstetric ward.

More than half women evaluated midwives work and the information provided during childbirth and the postnatal period in delivery and obstetrics units as very good. More than half of the women said that childbirth and post-partum care expectations were completely fulfilled.

Women with higher education statistically significant more frequent delivery and obstetrics units' midwives work evaluated as very good and well than women with lower education. Statistically significant married women delivery and obstetrics units' midwives information provided evaluated as very good and well than unmarried women. Working women statistically significant post-partum care kept fully and partially justified of expectations of childbirth than unemployed women.

Correspondence to: alinuteliep@gmail.com

Gauta 2016-09-21 